\title{
Geographic distribution, habitat association, and conservation status of the Critically Endangered Minas Gerais Tyrannulet Phylloscartes roquettei
}

\author{
LEONARDO E. LOPES, MARCOS MALDONADO-COELHO, DIEGO \\ HOFFMANN, EDSON R. LUIZ and SANTOS D'ANGELO NETO
}

\begin{abstract}
Summary
The Minas Gerais Tyrannulet Phylloscartes roquettei is currently classified as a Critically Endangered species, and is one of the most poorly known Neotropical birds. Here we report seven new localities for the species in the São Francisco river basin, raising to 17 the number of localities where this species is known to occur. The range of this species was estimated at 33,500 $\mathrm{km}^{2}$, covering a wider habitat spectrum than previously thought, including, in addition to dry forests, riparian and semi-deciduous forests. We believe this species is overlooked because its voice is generally unknown and available plates in field guides are inaccurate.
\end{abstract}

\section{Resumo}

O cara-dourada Phylloscartes roquettei é atualmente classificado como Criticamente Ameaçado, sendo uma das espécies de aves Neotropicais menos conhecidas. Neste trabalho são apresentadas sete novas localidades de ocorrência da espécie para a bacia do Rio São Francisco, elevando para 17 o número de localidades onde ela é conhecida. A área de ocorrência desta espécie foi estimada em $33,500 \mathrm{~km}^{2}$, ocupando uma gama de hábitats mais ampla do que o suposto anteriormente, incluindo, além das florestas secas, as florestas ciliares e semidecíduas. Acredita-se que esta espécie esteja passando despercebida devido ao desconhecimento de sua voz e à imprecisão das pranchas nos guias de campo disponíveis.

\section{Introduction}

The Minas Gerais Tyrannulet (Phylloscartes roquettei) was until recently known only from the type locality, "Brejo Januária" in the northern state of Minas Gerais, Brazil. This species was described almost 80 years ago (Snethlage 1928), but was rediscovered only in 1977, near the type locality (Willis and Oniki 1991). Its extremely restricted range, associated with its supposed dependence on dry forests, a rapidly disappearing habitat, resulted in the classification of the Minas Gerais Tyrannulet as Critically Endangered (Collar et al. 1992, BirdLife International 2006). The Minas Gerais Tyrannulet has been recently recorded in several new localities, and it is now known from ten published localities, mostly in the São Francisco river basin, but with one recent record from the Jequitinhonha river basin (Raposo et al. 2002, Fitzpatrick 2004, Luiz et al. 2006, Vasconcelos et al. 2006a, b). 
During the last 10 years we have worked extensively in the state of Minas Gerais, exploring almost all regions of the state, but only recently we recorded this species. Since then, we have recorded the Minas Gerais Tyrannulet in seven new localities. The majority of those records were documented by tape recordings that have been or will be deposited in the Arquivo Sonoro Professor Elias Coelho, Universidade Federal do Rio de Janeiro, Brazil. The new site records are as follows:

\section{Fazenda Capão Queimado, Cachoeira da Prata, Minas Gerais}

Three individuals were observed and tape-recorded during most of June and July in 1999 and 2000 ( $19^{\circ} 32^{\prime} 21^{\prime \prime} \mathrm{S}$ and $44^{\circ} 29^{\prime} 42^{\prime \prime} \mathrm{W} ; 804 \mathrm{~m}$ a.s.l.). This area is located in the Paraopeba river valley, a tributary of São Francisco river. The natural vegetation in this region is a mosaic of semi-deciduous forests, gallery forests along river courses and different subtypes of cerrado. In this area, individuals were regularly observed in patches of gallery forest surrounded by areas of abandoned pastures in which tall secondary forests have developed. Additional fieldwork during 2004, 2005 and 2006 failed to find this species again at this locality. The lack of re-sightings indicates a very small population size and that the species may be on the brink of extinction in this area.

\section{Morro Bom Sucesso, Paracatu, Minas Gerais}

Three individuals were observed in a patch of dry forest situated on top of limestone outcrops $\left(17^{\circ} 07^{\prime} 22^{\prime \prime} \mathrm{S}\right.$ and $46^{\circ} 48^{\prime} 24^{\prime \prime} \mathrm{W} ; 700 \mathrm{~m}$ a.s.l.). This forest patch suffered from selective logging and occasional fires. Some emergent trees reached $20 \mathrm{~m}$ in height, and the main trees recorded were Protium heptaphyllum (March.) (Burseraceae), Celtis brasiliensis (Gardner) (Ulmaceae) and Enterolobium contortisiliquum (Vell.) (Mimosaceae). Two individuals were observed foraging in a tall legume tree on 9 September 1997 and another solitary individual was recorded foraging in a similar tree on the following day, approximately $500 \mathrm{~m}$ away from the first record. All individuals were observed foraging through aerial attacks on the undersurface of mid- and canopy-strata leaves. We also recorded Wagler's Woodcreeper Lepidocolaptes wagleri, a dry forest endemic (Silva and Straube 1996). The future of this population is uncertain given that the block of dry forest in which individuals were observed might have been suppressed for limestone mining.

\section{Fazenda do Gama, Lassance and Três Marias, MG}

One individual was observed in 12 July 2005 in the mid-strata of a riparian forest, at the edge of a natural small lake ( $18^{\circ} \mathrm{Oz}^{\prime} 47^{\prime \prime} \mathrm{S}$ and $44^{\circ} 59^{\prime} 29^{\prime \prime} \mathrm{W} ; 780 \mathrm{~m}$ a.s.l.). This forest was similar to the cerradão, a forested semi-deciduous forest formation of the cerrado. This individual was taperecorded and promptly responded to the playback. Other species recorded in the area were typical of the cerrado, such as the Vulnerable Chestnut-bellied Guan Penelope ochrogaster. This is one of the few recent records of this guan in the São Francisco (Pereira and Brooks 2006). Currently, native forests are fragmented in this region and the few remaining patches constitute narrow strips of gallery forest along small creeks embedded in a matrix of Eucalyptus plantations. The remnant population of Minas Gerais Tyrannulet is probably very small and isolated.

\section{Fazenda Agropop, São Joaquim and Januária, MG}

One specimen was observed and tape-recorded in the canopy and mid-strata of a dry forest growing on top of limestone outcrops ( $15^{\circ} 36^{\prime} \mathrm{O}^{\prime \prime} \mathrm{S}$ and $44^{\circ} 4 \mathrm{O}^{\prime} 17^{\prime \prime} \mathrm{W} ; 483 \mathrm{~m}$ a.s.l.), near the 
Pandeiros river, on I April 2005. This forest patch is embedded in a cerrado matrix and is $20 \mathrm{~m}$ high, with some emergent trees reaching $25 \mathrm{~m}$. Six additional individuals were observed between 20 and 22 April 2006, foraging at different sites in the same forest patch. Two individuals were associated with a mixed-species flock composed of Olivaceus Woodcreeper Sittasomus griseicapillus, Wagler's Woodcreeper, Gray-headed Spinetail Cranioleuca semicinerea, Blacktailed Tityra Tityra cayana, Tropical Gnatcatcher Polioptila plumbea, Hooded Tanager Nemosia pileata, Guira Tanager Hemithraupis guira, Chestnut-vented Conebill Conirostrum speciosum and Tropical Parula Parula pitiayumi. The avifauna of this area is composed of elements typical of both the dry forests of central Brazil (sensu Silva and Oren 1992, e.g. Wagler's Woodcreeper, Reiser's Tyrannulet Phyllomyias reiseri and Caatinga Black-tyrant Knipolegus aterrimus), and of the Caatinga (sensu Pacheco 2003, e.g. Stripe-backed Antbird Myrmorchilus strigilatus and Silvery-cheeked Antshrike Sakesphorus cristatus). The Fazenda Agropop is located in the Refúgio da Vida Silvestre Rio Pandeiros, a recently created conservation unit of about 6,100 ha. However, swamps are the predominant vegetation, with only a small proportion covered by seasonally flooded forests, dry forests and cerrado. Despite the recent creation of this reserve, the future of this population is uncertain. Although several dry forests growing over limestone outcrops exist in the vicinity of this conservation unit, they are often illegally burned and logged. Importantly, these forests represent one of largest blocks of dry forests remaining in the region, with some of them reaching hundreds of hectares, and may harbour one of the largest known populations of the Minas Gerais Tyrannulet.

\section{Fazenda Corredor, Bocaiúva, Minas Gerais}

Two individuals were observed and tape-recorded foraging in the canopy of a dry forest on 18 July 2006 ( $17^{\circ} 23^{\prime} 29^{\prime \prime} \mathrm{S}$ and $43^{\circ} 53^{\prime} 58^{\prime \prime} \mathrm{W} ; 890 \mathrm{~m}$ a.s.l.). On the following day, probably the same individuals were observed foraging in association with a mixed-species flock composed of Whiteedged Piculet Picumnus albosquammatus, Scaled Woodcreeper Lepidocolaptes squammatus, Tropical Parula, Tropical Gnatcatcher and Blue Dacnis Dacnis cayana. Two additional individuals were detected in a similar nearby habitat $\left(17^{\circ} 24^{\prime} \mathrm{O} 4^{\prime \prime} \mathrm{S}\right.$ and $43^{\circ} 54^{\prime} 41^{\prime \prime} \mathrm{W}, 840 \mathrm{~m}$ a.s.l.). All birds were observed in deciduous forests, which are restricted to isolated limestone outcrops observed along temporary drainages in this area. These outcrops are surrounded by a matrix of Cerrado. Those forests are 10-15 $\mathrm{m}$ high, and during our visit only trees situated in the deeper and more humid valleys, where some emergent trees reached $20 \mathrm{~m}$, maintained leaves. The avifauna of this area is a mix of Caatinga elements (e.g. Stripe-backed Antbird and Silvery-cheeked Antshrike), cerrado species (sensu Silva 1991, Silva and Bates 2002, e.g. Curlcrested Jay Cyanocorax cristatellus and the Safron-billed Sparrow Arremon f. flavirostris) and a few Atlantic Forest birds (Silva et al. 2004, e.g. White-shouldered Fire-eye Pyriglena leucoptera). Another interesting species recorded in the area is Caatinga Black-tyrant, an uncommon endemic of the dry forests of central Brazil (Silva and Oren 1992, Silva and Bates 2002, Pacheco and Olmos 2006). Although the sites where this species was recorded constitute legal reserves ("Reservas Legais"), they are predominantly composed of savannah-like formations, suggesting a reduced population size of the Minas Gerais Tyrannulet.

\section{Fazenda Brejão, Brasilândia de Minas, Minas Gerais}

Two individuals were observed and tape-recorded on 24 July 2006 in the riparian forests of Paracatu river ( $17^{\circ} 04^{\prime} 26^{\prime \prime S}$ and $45^{\circ} 54^{\prime} 13^{\prime \prime} \mathrm{W} ; 500 \mathrm{~m}$ a.s.l.). On the following day, two additional individuals were observed foraging in the canopy, associated with a pair of Masked Gnatcatcher Polioptila dumicola. The riparian forest is $15-20 \mathrm{~m}$ high and semi-deciduous, with some areas covered by terrestrial bromeliads (gravatás). We observed no signs of limestone outcrops, but large outcrops were observed around $20 \mathrm{~km}$ apart. The avifauna of this area is typical of the 
cerrado, with several gallery forest endemics, such as Henna-capped Foliage-gleaner Hylocryptus rectirostris, Helmeted Manakin Antilophia galeata and Large-billed Antwren Herpsilochmus longirostris. In this area, we also recorded the dry forest endemic Wagler's Woodcreeper. The Fazenda Brejão is essentially covered by savannah-like formations, and only the riparian forests along the Paracatu river seem to constitute suitable habitat for the Minas Gerais Tyrannulet. Even though these riparian patches are considered legal reserves, population size is probably small because of the reduced amount of suitable habitat.

\section{Fazenda Santa Cruz, Felixlândia, Minas Gerais}

Two individuals were observed and tape-recorded on 30 July 2006 in a deciduous forest along a temporary drainage ( $18^{\circ} 43^{\prime} \mathrm{O} 1^{\prime \prime} \mathrm{S}$ and $45^{\circ} \mathrm{O}^{\prime} 45^{\prime \prime} \mathrm{W} ; 63 \mathrm{O} \mathrm{m}$ a.s.l.). The forest strip was $6-8 \mathrm{~m}$ high growing over slate soils and approximately $20 \mathrm{~m}$ wide. The adjacent cerrado was over rocky soil and very dry, physiognomically similar to the north-eastern Brazilian Caatinga. Two additional individuals were heard in a nearby semi-deciduous forest $15-20 \mathrm{~m}$ high $\left(18^{\circ} 44^{\prime} 36^{\prime \prime} \mathrm{S}\right.$ and $45^{\circ} \mathrm{O}^{\prime} 34^{\prime \prime} \mathrm{W} ; 650 \mathrm{~m}$ a.s.l.). During our visit, this area was still humid and the trees had green leaves. Both areas are located no more than $10 \mathrm{~km}$ from the Três Marias dam. The avifauna of the Fazenda Santa Cruz is typical of the cerrado, with species such as Henna-capped Foliagegleaner and Helmeted Manakin, and a few Atlantic Forest elements (Silva et al. 2004, e.g. Rufous-headed Tanager Hemithraupis ruficapilla). During an avifauna monitoring programme, one individual was found dead in a mist-net, probably as a consequence of the cold weather in the early morning. This individual (Figure 1), the fourth known specimen of the Minas Gerais Tyrannulet, was deposited in the Ornithological Collection of the Departamento de Zoologia da Universidade Federal de Minas Gerais, Belo Horizonte, Brazil (DZUFMG-5017). Analysis of the stomach contents showed only arthropods, of which we were able to identify five Coleoptera, one Hemiptera, one Formicidae and one Araneae. All arthropods eaten were remarkably small, and the heads of insects measured around $0.5 \mathrm{~mm}$ or even less. The specimen was a male, with slightly enlarged testes $(2 \mathrm{~mm} \times 1.6 \mathrm{~mm})$, and had the following measurements $(\mathrm{mm})$ : wing, 49.6; tail, 46.1; bill, 10.1; tarsus, 16.0. This and the other two known males are larger than the type specimen, the only known female. The mean wing measurements of males are around $8 \%$ larger than that of the females, a percentage similar to that shown by P. parkeri (Fitzpatrick and Stotz 1997). Although the sites in which we recorded this species constitute legal reserves, all

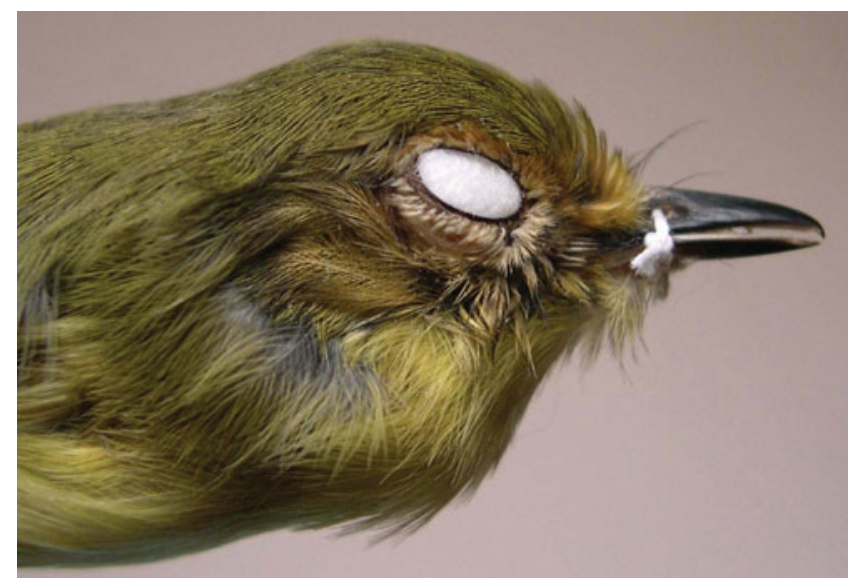

Figure 1. A male Minas Gerais Tyrannulet Phylloscartes roquettei collected in the Fazenda Santa Cruz, Felixlândia, Minas Gerais. 
forest patches are small and isolated within an extensive matrix of Eucalyptus plantations. Similar to the previous areas, population size here is apparently reduced.

\section{Conservation status}

The recent records of the Minas Gerais Tyrannulet resulted in a large range extension (Figure 2), suggesting that this species may not be as threatened as previously thought. The three main factors used to consider the Minas Gerais Tyrannulet as Critically Endangered (Collar et al. 1992, Fitzpatrick 2004, BirdLife International 2006) were: (1) restricted range, (2) specialized habitat and (3) high rate of habitat loss. The recent records of Minas Gerais Tyrannulet demonstrated that two of these threats are not as severe as previously thought.

\section{Range size}

The Minas Gerais Tyrannulet is now known to occur in 17 localities ("Januária W" of Willis and Oniki (1991) are too close to the type locality to be considered a distinct locality), mainly along the São Francisco river and small tributaries from Mocambinho to Felixlândia, and also occurs in four large tributaries named the Paracatu, Jequitaí, das Velhas and Paraopeba rivers. This species is also known to occur disjunctly in the Jequitinhonha river basin (Luiz et al. 2006), but this gap of about $200 \mathrm{~km}$ may only be a consequence of poor sampling. A conservative estimate of the

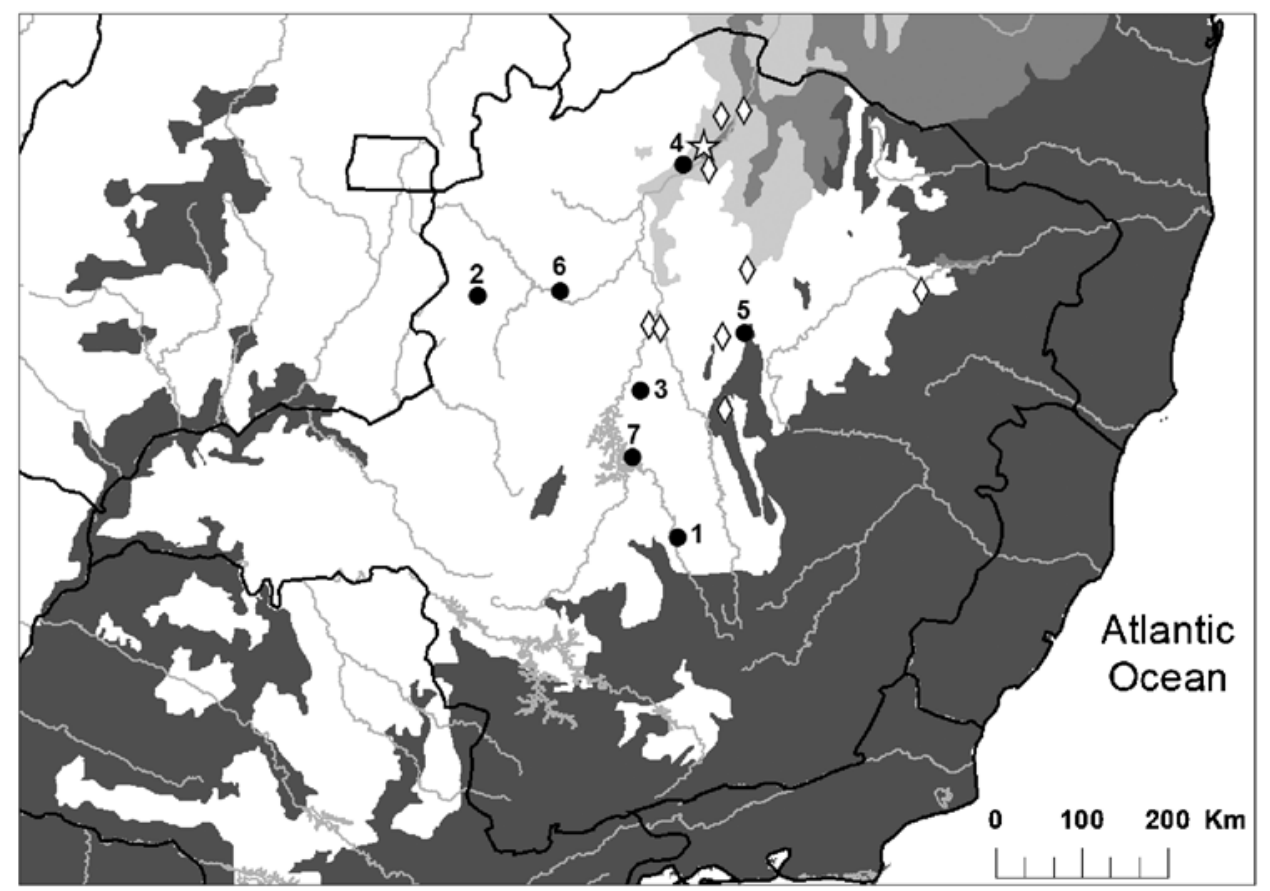

Figure 2. Map showing the known range of the Minas Gerais Tyrannulet Phylloscartes roquettei in south-eastern Brazil. Numbers refer to the new site records (black circles) in the same order as reported in the text. The type locality (star) and the previously know records (diamonds) are also depicted. Dark grey represents the Atlantic Forest domains, medium grey the Caatinga, light grey the dry forests of north-eastern Brazil and white the cerrado. (Modified from Olson et al. 2001.) 
range for this species covers an area of $33,500 \mathrm{~km}^{2}$, much larger than the $50 \mathrm{~km}^{2}$ estimated previously (BirdLife International 2006).

This new estimate shows the range of the Minas Gerais Tyrannulet is not unusually small when compared with the typical range of other members of Phylloscartes and Pogonotriccus (Figure 3), closely related genera (Fitzpatrick 2004). In fact, seven Phylloscartes and two Pogonotriccus species have ranges smaller than the Minas Gerais Tyrannulet according to range estimates from maps depicted in InfoNatura (2004).

\section{Habitat}

The Minas Gerais Tyrannulet is not restricted to dry forests as previously suggested, being also found in semi-deciduous and riparian forests present in the cerrado region. This species does not seem to occur in savannah-like vegetation, the predominant habitat in the cerrado. The elevation range of this species is 450-900 $\mathrm{m}$ a.s.l. Habitats where this species has been recorded include secondary-growth and fragmented forests (Raposo et al. 2002, pers. obs.), suggesting that it might not be strictly dependent on pristine forests. However, the birds observed might be the remnants of larger populations that existed before deforestation. Given the poorly known habitat requirements of this species, it is necessary first to assess the persistence of these populations in secondary forests before accepting this hypothesis.

\section{Habitat loss}

The main threat to this species is habitat loss. Dry forests are one of the most threatened habitats on Earth (Stotz et al. 1996, Miles et al. 2006), and the cerrado biome is subject to an unprecedented rate of destruction. It has been estimated that the entire biome may disappear by 2030 if the current rate of development is maintained (Machado et al. 2004). In Minas Gerais,

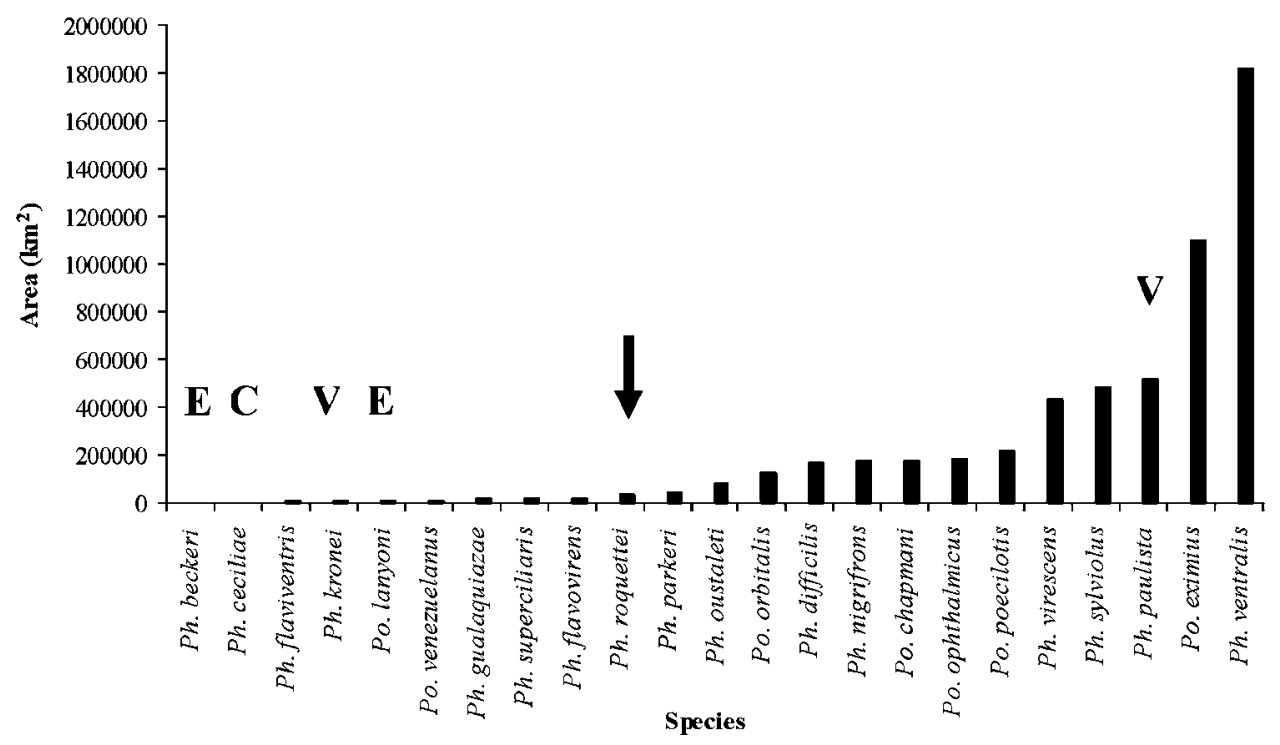

Figure 3. Range size of all known Phylloscartes (Ph.) and Pogonotriccus (Po) species. Letters indicate the conservation status of each species: C, Critically Endangered; E, Endangered; V, Vulnerable. The arrow indicates the Minas Gerais Tyrannulet Phylloscartes roquettei. 
suitable habitats (i.e. dry forests, semi-deciduous forests and gallery forests) are being quickly destroyed for the production of charcoal and cattle ranching (Kirwan et al. 2001, Raposo et al. 2002, all authors pers. obs.).

This accelerated rate of deforestation within its range and its presumably low density should be taken into account when making any decisions concerning the bird's conservation status. Although we lack accurate data on deforestation rates for the São Francisco river valley, most of the forest habitats have disappeared from all major tributaries, including the Velhas, Paraopeba and Paracatu rivers (Raposo et al. 2002, Kirwan et al. 2004, all authors pers. obs.). In addition, available literature generally reports only a few individuals (Raposo et al. 2002, Kirwan et al. 2004), and subsequent visits to sites where the species is known to occur sometimes failed to reveal any individual (Kirwan et al. 2004, M.M.-C. pers. obs.). The only conservation unit where this species has been recorded to date is the Cavernas do Peruaçu National Park, where no estimate of population size exists. All other areas where this species is present are fragmented and/or have been cleared for pastures and charcoal production (Raposo et al. 2002, Luiz et al. 2006, all authors pers. obs.).

Despite all new records at new localities and additional information on habitat use, both the elevated habitat loss and reduced density of the Minas Gerais Tyrannulet throughout its range call for a conservative approach concerning its conservation status. Further surveys designed to gather additional information on the distribution, habit use, local density and percentage of suitable habitat remaining are still required for a more thorough and accurate assessment of the threat status of the Minas Gerais Tyrannulet.

\section{An overlooked species?}

The Minas Gerais Tyrannulet is a poorly known species, and only a few ornithologists have observed it either in the field or in a museum. The examination of the type specimen by L.E.L. in the Museu Nacional, Rio de Janeiro (MNRJ) showed that the available plates in field guides are generally inaccurate. The illustration in BirdLife International (2000) shows a very dark upperparts and a lighter uropygium not observed in the type specimen or any other examined specimen. The forehead and lores are not pale red, but yellowish-ochre (Figure 1). Two field guides of Brazilian birds make no mention of this species (Souza 2002, Frisch and Frisch 2005) and the only other available field guide for Brazilian ornithologists (Sigrist 2006), depicts a marked black ear patch, not present in this species. The illustration in Fitzpatrick (2004) is fairly accurate, although less so than the original description (Snethlage 1928).

The poor quality and inaccuracy of the available plates and descriptions, associated with the fact that its voice is known to few ornithologists, makes field identification of this species very difficult. In fact, the specimen recently discovered in the museum of PUC-Minas (Vasconcelos et al. 2006b) remained misidentified as a Yellow-breasted Flycatcher Tolmomyias flaviventris, and later as a Yellow Tyrannulet Capsiempis flaveola, for 16 years. The type specimen in Museu Nacional was also tentatively identified as Capsiempis flaveola flaveola (Gonzaga 1989).

The yellow-ochre lores of this species (Figure 1 ) are hardly seen under field conditions, mainly because of the tiny size of the bird and the poor light conditions prevalent in forest canopy. Even when examining museum specimens, the yellowish-ochre lores are not as prominent as depicted in some plates (e.g. BirdLife International 200o). The inaccuracy of some plates and descriptions, associated with the difficulty in observing the yellowish-ochre lores in the field, have already been highlighted by other observers (Willis and Oniki 1991, Raposo et al. 2002).

We expect that making recordings of the Minas Gerais Tyrannulet available (deposited by the authors in http://www.xeno-canto.org.) will help ornithologists to record this species at new localities. Areas where the Minas Gerais Tyrannulet can potentially occur are the Paranã river valley, the Cauaia area in the Distrito Federal, and the Serra Geral in the states of Goiás, Tocantins and Bahia. All these areas are covered by dry forests, and are known to harbour the Caatinga Black-tyrant (Silva and Oren 1992, Bornschein et al. 2003, Pacheco and Olmos 2006) a 
species with similar habitat requirements. Another area within which this species can occur is the dry forests of western Bahia and southern Piauí, where two dry forest species found in the northern state of Minas Gerais (Moustached Woodcreeper Xiphocolaptes falcirostris and Wagler's Woodcreeper) also occur (Silva and Straube 1996). In Minas Gerais, we might also find this species in the recently created Mata Seca State Park, municipality of Manga, which constitutes about 10,300 ha. The dry forests along the road BR-135, municipality of Buenópolis, consisting of some few hundred hectares, are also of potential interest.

\section{Acknowledgements}

Logistic support for the fieldwork of L.E.L. and D.H. was supplied by V \& M Florestal and Marcos Rodrigues. Jorge Nacinovic and Marcos Raposo (MNRJ) permitted us access to their collection. Marcelo F. de Vasconcelos kindly prepared the specimen. We thank Robert Ridgely and InfoNatura for making range maps of the studied species freely available on the World Wide Web. L.E.L. and M.M.-C. are supported, respectively, by a fellowship granted by FAPEMIG and an overseas fellowship by the CNPq, Brazil.

\section{References}

BirdLife International (2000) Threatened birds of the world. Barcelona and Cambridge, U.K: Lynx Edicions and BirdLife International.

BirdLife International (2006) Species factsheet: Phylloscartes roquettei. BirdLife International. Available at: http:// www.birdlife.org/datazone/ebas/index.html. Accessed on: 18 September 2006.

Bornschein, M. R., Cáceres, N. C., Ferreira, W. V., Freitas, D. R. and Pichorim, M. (2003) Primeiro registro de Knipolegus aterrimus Kaup, 1853 no Brasil (Tyrannidae). Ararajuba 11: 141-144.

Collar, N. J., Gonzaga, L. P., Krabbe, N., Madroño Nieto, A., Naranjo, L. G., Parker III, T. A. and Wege, D. C. (1992) Threatened birds of the Americas: the ICBP/IUCN Red Data Book. Cambridge, U.K: International Council for Bird Preservation.

Fitzpatrick, J. (2004) Family Tyrannidae (Tyrant-flycatchers). Pp. $170-462$ in J. del Hoyo, A. Elliott and D. Christie, eds. Handbook of the birds of the world. Volume 9. Cotingas to pipits and wagtails. Barcelona, Spain: Lynx Edicions.

Fitzpatrick, J. and Stotz, D. F. (1997) A new species of Tyrannulet (Phylloscartes) from the Andean foothills of Peru and Bolivia. Ornithol. Monogr. 48: 37-44.

Frisch, J. D. and Frisch, C. D. (2005) Aves brasileiras e plantas que as atraem. São Paulo: Dalgas Ecoltec.

Gonzaga, L. P. (1989) Catálogo dos tipos na coleção do Museu Nacional. II: Passeriformes. Bol. Mus. Para. Emílio Goeldi Ser. Zool. 5: 41-69.

InfoNatura (2004) Birds, mammals, and amphibians of Latin America [web application]. Version 4.1. NatureServe. Available at: http://www.natureserve.org/infonatura. Accessed on: 9 October 2006.

Kirwan, G. M., Barnett, J. M. and Minns, J. (2001) Significant ornithological observations from the Rio São Francisco valley, Minas Gerais, Brazil, with notes on conservation and biogeography. Ararajuba 9: 145-161.

Kirwan, G. M., Barnett, J. M., Vasconcelos, M. F., Raposo, M. A., D'Angelo Neto, S. and Roesler, I. (2004) Further comments on the avifauna of the middle São Francisco Valley, Minas Gerais, Brazil. Bull. Brit. Ornithol. Club 124: 207-220.

Luiz, E. R., Ribon, R., Mattos, G. T. and Moraes, L. L. (2006) Discovery of Minas Gerais Tyrannulet Phylloscartes roquettei in the Jequitinhonha Valley, north-east Minas Gerais, Brazil. Cotinga 26: 84-86.

Machado, R. B., Ramos Neto, M. B., Pereira, P. G. P., Caldas, E. F., Gonçalves, D. A., 
Santos, N. S., Tabor, K. and Steininger, M. (2004) Estimativas de perda da área do Cerrado Brasileiro. Brasília: Conservação Internacional.

Miles, L., Newton, A. C., DeFries, R. S., Ravilious, C., May, I., Blyth, S., Kapos, V. and Gordon, J. E. (2006) A global overview of the conservation status of tropical dry forests. J. Biogeog. 33: 491-505.

Olson, D. M., Dinerstein, E., Wikramanayake, E. D., Burgess, N. D., Powell, G. V. N., Underwood, E. C., D'Amico, J. A., Itoua, I., Strand, H. E., Morrison, J. C., Loucks, C. J., Allnutt, T. F., Ricketts, T. H., Kura, Y., Lamoreux, J. F., Wettengel, W. W., P. H. and Kassem, K. R. (2001) Terrestrial ecoregions of the world: a new map of life on Earth. BioScience 51: 933-938.

Pacheco, J. F. (2003) Aves da Caatinga: uma análise histórica do conhecimento. Pp. 189-250 In J. M. C. Silva, M. Tabarelli, M. T. Fonseca and L. V. Lins, eds. Biodiversidade da Caatinga: áreas e ações prioritárias para a conservação. Brasília: Ministério do Meio Ambiente.

Pacheco, J. F. and Olmos, F. (2006) As aves do Tocantins 1: região sudeste. Rev. Bras. Ornitol. 14: 85-100.

Pereira, S. L. and Brooks, D. M. (2006) Conservando os cracídeos: a família de Aves mais ameaçadas das Américas. Misc. Publ. Houston Mus. Nat. Sc. 6: 1-115.

Raposo, M. A., Barnett, J. M., Kirwan, G. M. and Parrini, R. (2002) New data concerning the distribution, behaviour, ecology and taxonomic relationships of Minas Gerais Tyrannulet Phylloscartes roquettei. Bird Conserv. Int. 12: 241-253.

Sigrist, T. (2006) Aves do Brasil, uma visão artística. São Paulo, edited by the author.

Silva, J. M. C. (1991) Geographical variation in the Safron-billed Sparrow Arremon flavirostris. Bull. Brit. Ornithol. Club I11: 152-155.

Silva, J. M. C. and Bates, J. M. (2002) Biogeographic patterns and conservation in the South American Cerrado: a tropical savanna Hotspot. BioScience 52: 225-233.

Silva, J. M. C. and Oren, D. C. (1992) Notes on Knipolegus franciscanus Snethlage, 1928 (Aves: Tyrannidae), an endemic of central Brazilian dry forests. Goeldiana Zool. 16: 1-9.

Silva, J. M. C. and Straube, F. C. (1996) Systematics and biogeography of Scaled Woodcreepers (Aves: Dendrocolaptidae). Stud. Neotrop. Fauna Environ. 31: 3-10.

Silva, J. M. C., Souza, M. C. and Castelleti, C. H. M. (2004) Areas of endemism for passerine birds in the Atlantic forest, South America. Glob. Ecol. Biog. 13: $85-92$.

Snethlage, E. (1928) Novas espécies e subespécies de aves do Brasil central. Bol. Mus. Nac. 4: 1-7.

Souza, D. (2002) All the birds of Brazil. Feira de Santana, DALL.

Stotz, D. F., Fitzpatrick, J. W., Parker III, T. and Moskovits, D. K. (1996) Neotropical birds: ecology and conservation. Chicago, Illinois: University of Chicago Press.

Vasconcelos, M. F., D'Angelo Neto, S., Kirwan, G. M., Bornschein, M. R., Diniz, M. G. and Silva, J. F. (2006a) Important ornithological records from Minas Gerais state, Brazil. Bull. Brit. Ornithol. Club 126: 212-238.

Vasconcelos, M. F., Diniz, M. G., Guimarães, L. and Garzon, B. (2006b) O terceiro exemplar de Phylloscartes roquettei (Aves: Tyrannidae) descoberto no Museu de Ciências Naturais PUC Minas. CD Rom. In R. Ribon, ed. XIV Congresso Brasileiro de Ornitologia: Resumos. Ouro Preto: Universidade Federal de Ouro Preto, Sociedade Brasileira de Ornitologia.

Willis, E. O. and Oniki, Y. (1991) Avifaunal transects across the open zones of northern Minas Gerais, Brazil. Ararajuba 2: $41-58$.

\section{LEONARDO ESTEVES LOPES*, DIEGO HOFFMANN}

Laboratório de Ornitologia, Departamento de Zoologia, ICB, Universidade Federal de Minas Gerais, Av. Antônio Carlos, 6627, Pampulha, 31270-910, Belo Horizonte, MG, Brazil. 
MARCOS MALDONADO-COELHO

Department of Biology, University of Missouri-St. Louis, 8001 Natural Bridge Road 63121, St. Louis, Missouri, U.S.A.

\section{EDSON RIBEIRO LUIZ}

Birdlife International (Brazil Programme), Project Boa Nova, Rua Otávio Mangabeira 79, Centro, CEP 45250-ooo, Boa Nova, Bahia, Brazil.

\section{SANTOS D'ANGELO NETO}

Departamento de Biologia Geral, Universidade Estadual de Montes Claros, Avenida Rui Braga, s/no., 39401-089, Montes Claros, Minas Gerais, Brazil.

*Author for correspondence; e-mail: leo.cerrado@gmail.com

Received 17 January 2007; revision accepted 29 March 2007 